NOTES ON NATURAL HISTORY

\title{
Three Years Avifaunal Record from the Campus of State Forest Research Institute of Chhattisgarh, Raipur, India
}

\section{Anurag Vishwakarma', Jay Prakash George ${ }^{2}$, Krishnakant Lawania ${ }^{3}$, Krishna Chandra Yadav ${ }^{4}$ \\ 'North Eastern Regional Institute of Science and Technology, Nirjuli-791109, Itanagar, Arunachal Pradesh, India \\ ${ }^{2}$ State Forest Research Institute, Jabalpur, M.P., India \\ ${ }^{3}$ IIS university, Jaipur, Rajasthan, India \\ ${ }^{4}$ Forest Headquarter, Naya Raipur, Chhattisgarh, India}

\section{Introduction:}

The bird population is an indication of environmental changes as they respond fast to threats and changing environment conditions (Barov, 2011). The bioindicators of a different kind of environments like urbanization and industrialization disturb the avian habitats (Mohan \& Gaur, 2008, Gupta \& Singh, 2003). India accounts for 12 percent of the total number of bird species in the world, amounting to 10,135, among the 1306 species. Taxonomically, the bird population in the country is divided into 26 orders, 111 families, and 492 genera. Of these 72 species are endemic to India, constituting about $5.5 \%$ of the country's bird diversity (Praveen et al., 2018).

We tabulated the bird diversity in SFRTI campus which provide a well-organized niche for almost every kind of birds. There is no previous is available in such an organized undisturbed niche of Raipur like SFRTI. The place is spread over 63 ha area, and about 5 ha of the area is spaced for artificial seasonal wetland and rest of the area is planted by different experimental plots of trees like Acacia nilotica, Acacia catechu, Azadirachta indica, Phyllanthus emblica, Dalbergia sissoo, Terminalia arjuna, Bamboosa species, Santalum album, Eucalyptus species, Cleistanthus collinus and Tectona grandis etc. Teak (Tectona grandis) is the dominant species of campus.

\section{Ourobsevations:}

We tabulated birds in between Jan. 2013 to Dec. 2016 by direct visual count. The Observations were made in the morning between 6:00 to 9:00 am and evening between 5:00 to 6:30 pm. Birds were sighted using binocular $(8 \times 40)$ and Canon 55oD camera with 75-300 mm lens on the spot identification using field guide Grimmet et. al 2013. Breeding birds' nest were also considered in our study area and subsequently, this information was used to establish the status of resident species of the area. Finally, the relative percentages of the number of species to the respective family were calculated. During the study period
Study Area: Raipur, Chhattisgarh, India... Coordinated: $21^{\circ} 17^{\prime} 27.9^{\prime \prime} \mathrm{N} ; 81^{\circ} 43^{\prime} 40.7^{\prime \prime} \mathrm{E}$

Key words: Bird, Visual record, Wetland, Anthropogenic pressure of 2013 and 2014, our wetland site was surrounded by tall grasses and other shrub species which provided a protection boundary to wetland the human disturbance was also negligible there. But in the year 2015 the wetland area was reconstructed so due to heavy machine operation and their sound most of the species which were coming regularly during Monsoon season for breeding like Black Crown night heron (Nycticorax nycticorax), Lesser whistling duck (Dendrocygna javanica), \& Purple heron (Ardea purpurea) etc. not visited in study site and unfortunately in the same year rainfall was also low. Further, the surrounding areas of the newly built wetland cleaned by creating the ground fire which also decreased the population of apparent birds. In the following year 2016, the rainfall was satisfactory as compared to its preceding year which ultimately increased the occurrences of monsoon population of birds from 58 to 90 . The avian diversity could be regained by taking proper measures around the wetland (Chandra et al., 2014). From a conservation point of view, till date, the urban biodiversity for avian species has been given very little attention as compared to the natural and protected ecosystem (Jule 1997, Vanderrmeer 1997). Patvardhan et. al. (2000) have identified educational and defense premises that occupy less than $5 \%$ of the total urban area and are the hotspot for the urban biodiversity. The main aim of this study was to make comprehensive baseline information on the bird species for the future as well as to create awareness for their conservation. Rare and endangered species of birds, including migratory birds, were included in Schedule-I of the Wild Life (Protection) Act, 1972 thereby according to the highest degree of protection. During our study period, a total of 107 avifauna species belonging to 46 families and 18 orders were recorded. The highest species were recorded in family Ardeidae (10), Anatidae (9), Motacillidae (6), Accipitridae (5) and Muscicapidae (5) respectively. Shannon-Wiener

*Corresponding Author: aviwild88@gmail.com 


\section{NOTES ON NATURAL HISTORY}

diversity index $\left(\mathrm{H}^{\prime}\right)$, is highest (3.53) in 2016 and lowest (3.26) in 2013. Species richness was highest in 2016 and lowest in 2015.

Table -1: Birds seen during theyear 2013 to 2016 in SFRTI campus

Order:Accipitriformes, Family: Accipitridae

Milvus migrans, Elanus caeruleus, Accipiter badius, Pernis ptilorhynchus ${ }^{I}$, Butastur teesa ${ }^{I}$

Order:Anseriformes, Family:Anatidae

Anas poecilorhyncha, Dendrocygna javanica, Nettapus coromandelianus', Anas Penelope, Anus strepera', Anas querquedula ${ }^{I}$, Anus acuta ${ }^{l}$, Netta rufina ${ }^{I}$, Aythya fulingula ${ }^{I}$

Order: Bucerotiformes, Family:Bucerotidae, \& Upupidae Ocyceros birostris ${ }^{3}$, Upupa epops ${ }^{2}$

Order:Caprimulgiformes, Family:Caprimulgidae Caprimulgus asiaticus

Order: Charadriiformes, Family: Scolopacidae, Charadriidae Aclilis hypoleucos, Venellus indicus, Vanellus malabaricus, Tringa stagnatilis ${ }^{2}$, Charadrius dubius

Order:Ciconiiformes, Family: Ciconiidae Anastomus oscitans

Order:Columbiformes, Family: Columbidae Strepopelia Senegalensis, Streptopelia orientalis, Columba livia, Streptopelia chinensis ${ }^{2}$

Order: Coraciiformes, Family: Meropidae, Coraciidae, Alcedinidae

Merops orientalis, Coracius benghalensis, Alcedo atthis, Ceryle rudis, Halcyon smyrnensis

Order:Cuculiformes, Family: Cuculidae

Eudynamys scolopacea, Hierococcyx varius, Centropus (sinensis) parroti, Clamatorjacobinus ${ }^{1}$

Order: Galliformes, Family: Phasianidae Francolinus pondicerianus

Order: Gruiformes, Family: Acrocephalidae, Aegithinidae, Alaudidae, Cisticolidae, Corvidae, Dicaeidae, Dicruridae, Estrildidae, Hirundinidae, Laniidae, Leiothrichidae, Monarchidae, Motacillidae, Muscicapidae,Nectariniidae, Oriolidae, Passeridae, Phylloscopidae, Ploceidae, Pycnonotidae, Rhipiduridae, Sturnida, Vangidaee

Eremopterix grisea, Prinia socialis, Prinia inornatca, Dendrocitta vagabunda, Corvus splendens, Corvus culminatus, Dicaeum erythrorhychos, Prinia inornatca, Dendrocitta vagabunda, Corvus splendens, Corvus culminatus, Dicaeum erythrorhychos, Hirundo rustica, Turdoides striatus, Terpsiphone paradisi, Motacilla cinerea, Anthus rufulus, Motacilla maderaspatensis, Motacilla flava, Anthus rufulus, Saxicoloides fulicola, Nectarinia asiatica, Passer domesticus, Pycnonotus cafer, Oriolus oriolus, Grawpila Contra, Temenuchus pogodarum, Acriclotheres tristis, Cecropis daurica ${ }^{3}$, Phoenicurus ochruros ${ }^{3}$, Ploceus philippnus ${ }^{3}$, Phylloscopus trochiloides ${ }^{2}$, Phylloscopus griseolus ${ }^{2}$, Ficedula parva ${ }^{2}$, Motacilla alba ${ }^{2}$, Hirundo smithii', lanius vittatus ${ }^{2}$, Lonchura striata ${ }^{2}$, Amaurornis phoenicurus ${ }^{2}$, Tephrodornis pondicerianus ${ }^{1}$, Rhipidura aureola $^{2}$, Petronia xanthocollis ${ }^{\prime}$, Ficedula albicilla ${ }^{i}$, Cyornis tickelliae ${ }^{i}$, Anthus hodgsoni ${ }^{i}$, Dicrurus leueophaeus ${ }^{i}$, Orthotomus sutorius, ${ }^{1}$, Prinia sylvatica ${ }^{1}$, Mirafra erythroptera ${ }^{1}$, Iduna caligata ${ }^{\prime}$, Aegithina tiphia ${ }^{2}$,
Ambient Science, 2018: Vol. 05(Sp2); 58-59 DOI:10.21276/ambi.2018.05.sp2.nn02

Order: Pelecaniformes, Fam.:Ardeidae, Threskiornithidae

Nycticorax nycticorax, Bubulcus cromandus, Ardeola grayii, Ergetta garzetta, Ardea purpurea, Dupetor flavicollis ${ }^{3}$, Ergetta alba $^{3}$, Ixobrychus minutus ${ }^{2}$, Ixobrychus sinensis ${ }^{1}$, Egretta intermedia ${ }^{1}$, Threskiornis melanocephalus ${ }^{1}$

Order: Piciformes, Family: Megalaimidae Psilopogon haemacephalus

Order: Podicipediformes, Family: Podicipedidae Tachybaptus ruficollis ${ }^{3}$

Order: Psittaciformes, Fam.: Psittaculidae Psittacula cyanocephala ${ }^{2}$, Psittacula krameri ${ }^{2}$

Order: Strigiformes, Family: Tytonidae, Strigidae Bubo bengalensis ${ }^{2}$, Tyto alba1, Athene brama

Order:Suliformes, Family: Phalacrocoracidae Phalacrocoraxnigar, Phalacrocorax carbo ${ }^{2}$

${ }^{1}$ Seen only for one year; ${ }^{2}$ Seen only for two year; ${ }^{3}$ Seen only for three year (species without superscript seen in all the fouryears)

\section{Acknowledgements:}

Authors are thankful to Researcher Mr. Vivek Vaisnav, Ashutosh Pandey, Devendra Sharma, Amit Kumar Baghel and Mr. R. K. patley, Technical Assistant SFRTI for kind support during study time. Special thanks to Mr. R.K. Dey (Former director SFRTI, Raipur), Mr. A.M.K. Bharos (President, Chhattisgarh wildlife society) and Mr. Rajendra Yadav, quality Manager, C.G. certification society for their valuable guidance during ourstudy.

\section{References:}

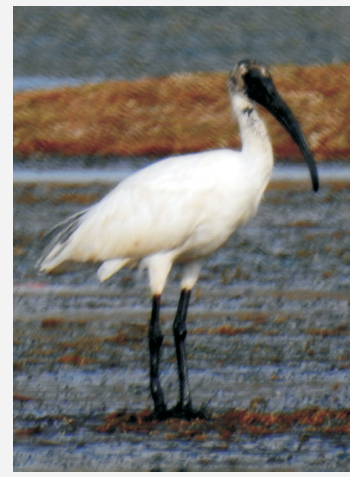

Threatened species: T. melanocephalus viewed in year 2014
Barov, B. (2011): Conservation and recovery of threatened birds in the European Union. : Rob Hume and Kerstin Sundseth edited BirdLife International. Pub. by: The Europea Union, Luxembourg.

Chandra, K., Dutta, S.K., Gupta, R.P. \& Raha, A. (2015): Diversity and Conservational Status of Avifauna in Bastar Plateau of Chhattisgarh, India. Ambient Sci., 2(1):31-43.

Grimmett, R., Inskipp, C., \& Inskipp, T. (2013): Birds of the Indian Subcontinent: India, Pakistan, Sri Lanka, Nepal, Bhutan, Bangladesh and the Maldives. Pub. by: Bloomsbury India. 448 p.

Gupta, A.K., \& Singh, S.K., (2003): Changing wetlands due to discharge of effluents from small scale industries around Varuna river corridor. Ecol. Environ. Conserv., 9(2):209-212.

Jule, W. (1997): Sightlines: Printmaking and Image Culture. Pub. by: The University of Alberta Press. $336 \mathrm{p}$.

Mohan, D. \& Gaur, A. (2007). Avian Diversity Around Jajiwal Pond -A Natural Wetland; in Proceeding of Taal 2007: 12th World Lake Conference, pp. 542-546

Patwardhan, A.A \& Gandhe, R.V. (2001): Tree diversity of Pune urban area: cosmetic increase? J. Ecol. Soc., 13/14:21-33.

Praveen J., Jayapal, R., \& Pittie, A. (2016): A checklist of the birds of India. Indian BIRDS, 11:113-170. 